\title{
Da homossexualidade à "homoafetividade": trajetórias adotivas no Rio de Janeiro
}

Alessandra de Andrade Rinaldi*

\section{Resumo}

Em razão da decisão do Supremo Tribunal Federal (STF), que em 2011 reconheceu a união estável de pessoas do mesmo sexo, ações de adoções começaram a ser ajuizadas por pessoas de declarada orientação homossexual. Até essa data, de acordo com o art. 39, § $2^{\circ}$ da lei 12010/09, para adoção conjunta era indispensável que os adotantes fossem casados civilmente ou mantivessem união estável comprovada. Por conseguinte, pares homossexuais encontravam dificuldades de viabilizar um projeto de filiação conjunta. Em razão disso, indivíduos que viviam uma união consensual decidiam adotar sozinhos. Sendo assim, o trabalho proposto busca analisar qual o tratamento jurídico dado a essa prática, na Comarca do Rio de Janeiro, quando os processos e as habilitações em adoção são movidos em âmbito da conjugalidade homossexual.

\section{Palavras-chave}

Adoção. Homossexualidade. Família.

\begin{abstract}
Due to The Supreme Court's (Supremo Tribunal Federal - STF) decision, which recognized the same-sex civil union in 2011, adoption lawsuits started to be filed by people with declared homosexual orientation. Until that date, according to the article 39 § 2 of the Law 12010/09, in order to have a joint adoption (two-sided), it was required that the adopters were legally married or living a recognized stable civil union. Therefore, homo-affective couples found it difficult to have a joint (two-sided) adoption. However, once legally recognized, a few gay and lesbian couples decided to adopt their partners' children, whether biological or not. This piece aims at making an analysis regarding the legal treatment for this specific kind of case, in Rio de Janeiro County.
\end{abstract}

\section{Keywords}

Adoption. Homosexuality. Family.

\footnotetext{
* Antropóloga e professora da Universidade Federal Rural do Rio de Janeiro.
} 


\section{Introdução}

Entre os anos de 2009 a 2011, desenvolvi, com apoio da FAPERJ, a pesquisa "A genetização do parentesco, adoção e o impacto na questão da infância e adolescência no município do Rio de Janeiro". Naquele momento, havia o propósito de apreender o que moveria indivíduos ou casais a ingressarem com uma ação de adoção no município do Rio de Janeiro. Ao iniciar a investigação, tinha por objetivo analisar como as prescrições de gêneros levariam homens e mulheres "inférteis" a buscarem a filiação adotiva como alternativa a um projeto parental "biológico-natural sem sucesso". Ao longo de sua execução, comecei a problematizar a exclusividade dessas prescrições ao notar que valores morais, laços locais de solidariedade, relações de parentesco e de amizade, além da vontade de perfilhar a prole do (a) parceiro (a) afetivo (a) e uma nova concepção sobre adoção poderiam influir na busca por uma "filiação socioafetiva"1.

Sendo assim, em 2012, optei por desdobrar as análises realizadas em âmbito daquela investigação no município do Rio de Janeiro por meio de um novo projeto, "Adoção em seus múltiplos sentidos", através do qual procurei apreender os diversos sentidos da adoção por meio de análises documentais em processos e habilitações em adoção²; através de etnografia em Grupos de Apoio à Adoção (GAA); de entrevistas com pais adotivos e/ou "requerentes"; com integrantes do Poder Judiciário (os membros das Varas da Infância, da Juventude e do Idoso), com membros da Defensoria Pública, com Promotores da Infância e da Juventude, e com integrantes dos Grupos de Apoio à Adoção. Busquei entender as visões sobre família, parentesco e os diferentes sentidos que cada personagem integrante desse cenário constrói sobre o tema.

Além disso, no que tange aos documentos, procurei analisar comparativamente o tratamento jurídico dado à prática adotiva requerida tanto por heterossexuais quanto por homossexuais antes e após o ano de 2009. A proposta comparativa se justificava, uma vez que, em âmbito da pesquisa "A genetização do parentesco", os dados levantados diziam respeito aos anos de 2000 a 2006. Não havia trabalhado nenhum documento iniciado

\footnotetext{
${ }^{1}$ Uso aspas para marcar as categorias provenientes do campo pesquisado.

${ }^{2}$ Habilitação é um procedimento administrativo obrigatório e prévio à adoção. Após a Lei 12010 foi tornada obrigatória. Sua composição será discutida à frente.
} 
após a promulgação da Lei 12010/2009, conhecida como a "Nova Lei da Adoção"'. Sendo assim, a ideia era a de centrar no período de 2000 até os dias atuais, de forma a analisar a tramitação processual antes e após a referida Lei, além das ações movidas posteriormente à decisão do Supremo Tribunal Federal (STF) brasileiro que, em maio de 2011, equiparou casais heterossexuais e homossexuais, em termos de direitos. Tal reconhecimento pôde possibilitar a adoção conjunta por pares homossexuais, porque, uma vez reconhecidos como casais em união estável, tornam-se virtualmente aptos a se habilitarem conjuntamente.

Para o presente artigo, minha proposta foi a de abordar os processos de adoção abertos por casais de gays e de lésbicas. Por meio da análise desses documentos, intencionei apreender: a) como são construídos, nos processos, os motivos que levam homossexuais à adoção; b) como aparecem nesses documentos as visões sobre o assunto produzidas por integrantes do Poder Judiciário (juízes, membros da equipe técnica - psicólogos e assistentes sociais), membros da Defensoria Pública e promotores que militam na área da infância e da juventude ${ }^{4}$.

\section{0 processo como objeto de análise}

Para efetuar a pesquisa documental que abordo neste texto, usei métodos qualitativos com o propósito de coletar e produzir dados sobre a adoção no município do Rio de Janeiro. Para tanto, foram fontes os processos envolvendo adoção de crianças e adolescentes que tramitavam nas Varas da Infância, Juventude e do Idoso da Comarca do Rio de Janeiro. Dentre as três existentes -Vara de Infância Juventude e do Idoso da Comarca da Capital (VIJI), $1^{\underline{a}}$ Vara da Infância da Juventude e do Idoso ( $\left.1^{\circ} \mathrm{VIJI}\right)$, regional de Madureira e $2^{\underline{a}}$ Vara da Infância da Juventude e do Idoso $\left(2^{\circ} \mathrm{VIJI}\right)$, regional de Santa Cruz - realizei levantamento em duas, nas regionais de Santa Cruz

\footnotetext{
${ }^{3}$ Essa Lei dispõe sobre adoção; altera as Leis nos 8.069, de 13 de julho de 1990 - Estatuto da Criança e do Adolescente, 8.560, de 29 de dezembro de 1992; revoga dispositivos da Lei no 10.406, de 10 de janeiro de 2002 - Código Civil, e da Consolidação das Leis do Trabalho - CLT, aprovada pelo Decreto-Lei no 5.452, de 1o de maio de 1943.

${ }^{4}$ A noção de campo jurídico, cunhada por Pierre Bourdieu (1989) pôde iluminar meu percurso analítico por proporcionar o entendimento de que as práticas e os discursos jurídicos são efeitos e/ou produtos de saberes que são elaborados tanto internamente quanto externamente ao universo do direito.
} 
e de Madureira, uma vez que não foi dada autorização para a realização da pesquisa na VIJI Comarca da Capital.

Ao todo coletei 125 processos, sendo que cinco dizem respeito à adoção realizada por casais de gays e de lésbicas ${ }^{5}$. Dentre esses cinco de que trata a presente análise, três foram processos abertos em 2011 por gays que pleitearam conjuntamente a adoção. Um deles chegou aos filhos após habilitação e início de visitação às instituições de acolhimento. Outros dois, por meio de participação em "programas de apadrinhamento afetivo”. Desses dois, um foi iniciado em 2005, mas a adoção ocorreu em 2011, quando os "requerentes" participaram de um "programa de apadrinhamento afetivo" no Rio de Janeiro e acabaram adotando um adolescente.

Dois outros envolvem casais de lésbicas. Uma ação foi proposta com a intenção de filiar o filho adotivo da companheira, em 2012. Outro diz respeito ao requerimento realizado por duas mulheres que, ao viverem em regime de união estável, optaram pela adoção conjunta, em 2008. Chegaram à filha também por meio da participação em um "programa de apadrinhamento afetivo".

Em termos metodológicos, os processos foram vistos tal como proposto por Adriana Vianna (VIANNA, 2002:4). Entendi esse material como um conjunto de relatos convertidos em depoimentos escritos por um mecanismo de controle burocrático e de construção de afirmação de autoridade fundamentais para a produção de uma decisão judicial. Compreendi um "auto" como resultado de um confronto de posições de autoridade entre os que depõem e os que são responsáveis em traduzir as falas em termos da universalidade jurídica. Uma vez demarcado o poder desses últimos, o que se tem como resultado e/ou depoimento é algo que foi produzido sob condições de constrangimento.

Em termos de utilização dos documentos, trabalhei de forma desigual com o material. Ora usei relatórios psicossociais, ora petições iniciais produzidas por advogados ou defensores públicos, manifestações do Ministério Público e /ou sentenças. Em um caso, analisei um processo mais denso, composto

\footnotetext{
${ }^{5}$ De forma distinta ao trabalho realizado por Anna Paula Uziel (2007) utilizei exclusivamente documentos cujos requerentes eram declarados homossexuais nos "autos". Uziel (2007) realizou uma pesquisa sobre adoção pleiteada por pais homossexuais, dedicando-se a entender a visão do Poder Judiciário sobre o assunto por meio de entrevistas com operadores do direito e análise em processos. Ao buscar informações sobre a sexualidade dos adotantes, pautou-se não só nas peças processuais, mas também em informações dadas por parte dos técnicos do Poder Judiciário.
} 
por apelação cível proposta por adotantes em razão da delimitação do sexo e idade do filho pretendido e recurso do Ministério Público ao Supremo Tribunal Federal (STF) e ao Superior Tribunal de Justiça (STJ), alegando que casais do mesmo sexo não formam uma entidade familiar e, portanto, não poderiam adotar conjuntamente.

Essa forma pouco ortodoxa de análise se deveu também à natureza dos documentos. Alguns eram mais telegráficos, outros mais densos, e alguns estavam inacabados. Devido a isso, não poderia escolher compará-los sistematicamente. Posta essa dificuldade colocada pela natureza do material, procurei as peças, menos preocupada com o lugar que ocupavam e mais com o valor do discurso. Por isso, ao produzir minha análise, fiz o recorte demonstrativo em termos de relevância. Notei que, de um conjunto de múltiplas causas, algumas eram tornadas moralmente relevantes (EVANSPRITCHARD, 1978) constituindo-se na "verdade" sobre a possibilidade adotiva.

\section{A decisão do STF e o impacto na questão da adoção}

Em maio de 2011, o Supremo Tribunal Federal brasileiro julgou a Ação de Descumprimento de Preceito Fundamental ADPF 132 e a Ação Direta de Inconstitucionalidade ADI $4277^{6}$. A ADPF 132 foi de autoria do Governador do Estado do Rio de Janeiro, Sérgio Cabral. Segundo Chaves (2012: 231), requisitava-se que o STF interpretasse conforme Constituição Federal de

\footnotetext{
${ }^{6}$ Tanto a ADI n 4277 quanto a ADPF n 132 têm como objeto de análise a interpretação da Constituição Federal em seus artigos que referenciem aos princípios fundamentais e o artigo $\mathrm{n}^{\circ} 226$, e o Código Civil no seu artigo ${ }^{\circ} 1723$ e tem como cerne o debate sobre união entre pessoas do mesmo sexo como entidade familiar. A ADPF 132, ação apresentada pelo Governo do Rio de Janeiro, visou à garantia aos benefícios de licença, previdência e assistência. A ADI 4277, ação interposta pela Procuradoria-Geral da República, visou a que o STF declarasse como obrigatório o reconhecimento da união "homoafetiva" como entidade familiar. A ADPF - Arguição de Descumprimento de Preceito Fundamental - tem em seus objetivos viabilizar, em âmbito jurídico, ações com vistas a evitar ou, em última instância, reparar lesão a preceito fundamental, resultante de ato do Poder Público. Deste modo, passa a haver a possibilidade de se arguírem questões de relevante controvérsia constitucional relativa à lei, cujo objetivo é proteger os direitos fundamentais dos cidadãos, violados ou ameaçados por atos do poder público, desde que tenham sido esgotadas outras medidas de caráter objetivo, de modo a propor uma melhor interpretação constitucional. ADI - Ação Direta de Inconstitucionalidade - objetiva compreender se uma lei, ou parte dessa lei, está sendo operada de forma inconstitucional. Cabe ao Supremo Tribunal Federal concentrar seus esforços no desempenho da constitucionalidade frente à Carta da República.
} 
1988 o Estatuto dos Servidores Públicos Civis do Estado do Rio de Janeiro, aplicando analogicamente o art. 1723 do Código Civil brasileiro de 2002 às uniões estáveis "homoafetivas". Como pedido subsidiário, foi pleiteado que a ADPF fosse recebida como Ação Direta de Inconstitucionalidade, o que de fato aconteceu em 2009. Ainda segundo Chaves, nessa data a Procuradoria Geral da República propôs a ADPF 178, recebida pelo então presidente do STF, Ministro Gilmar Mendes, como ADI 4277.

Essa Ação Direta de Inconstitucionalidade teve o objetivo de que a união entre pessoas do mesmo sexo fosse reconhecida como entidade familiar. O STF julgou favoravelmente o pleito e dessa forma, segundo Dias (2011:207), como se tratou de uma ADI, a decisão teve "efeito vinculante" aos demais órgãos do Poder Judiciário e da administração pública. Segundo Vecchiatti (2012: XIII), essa decisão girou em torno da interpretação constitucional dos artigos $226 \S 3^{\circ 7}$ e do art. 1723 do Código Civil ${ }^{8}$. Através dessa interpretação, o STF reconheceu um quarto modelo de família brasileira: a "homoafetiva". A Constituição Federal até então havia reconhecido três tipos de família: 1) a decorrente de casamento (art. 226, parágrafo $1^{\circ}$ e $2^{\circ}$ ); 2) a decorrente de união estável entre pessoas de sexo diferente (art.226, parágrafo $3^{\circ}$ ); e 3) a família "monoparental", ou seja, aquela formada por apenas um dos pais e seus descendentes (artigo 228, parágrafo $4^{\circ}$ ).

Segundo Chaves (2012:244) ${ }^{9}$, os dez ministros votantes manifestaram-se pela procedência das ações. Reconheceram a união "homoafetiva" como entidade familiar e aplicaram, por analogia à mesma, o regime concernente à união estável regulamentada no art. 1723 do Código Civil de 2002. Os

\footnotetext{
${ }^{7}$ Artigo $226 \S 3$ "para efeito de proteção do Estado, é reconhecida a união estável entre o homem e a mulher como entidade familiar, devendo a lei facilitar a sua conversão em casamento".

${ }^{8}$ Artigo 1723 do Código Civil de 2001 "é reconhecida como entidade familiar a união estável entre o homem e a mulher, configurada na convivência pública, contínua e duradoura e estabelecida com o objetivo de constituição de família'”.

${ }^{9}$ Segundo Chaves (2012:244), em seu voto final, como relator, argumentou que o artigo $3^{\circ}$, inciso IV, da Constituição veda qualquer discriminação em virtude de sexo, raça, cor e que, nesse sentido, ninguém pode ser discriminado em função de sua preferência sexual. Os ministros Luiz Fux, Ricardo Lewandowski, Joaquim Barbosa, Gilmar Mendes, Marco Aurélio, Celso de Mello e Cezar Peluso, bem como as ministras Carmen Lúcia Antunes Rocha e Ellen Gracie acompanharam o entendimento do ministro Ayres Britto pela procedência das ações e com efeito vinculante, no sentido de dar interpretação conforme a Constituição Federal para excluir qualquer significado do artigo 1.723 do Código Civil que impeça o reconhecimento da união entre pessoas do mesmo sexo como entidade familiar.
} 
fundamentos constitucionais que embasaram foram os princípios da dignidade da pessoa humana (art. $1^{\circ}$, inciso III), da vedação à discriminação odiosa (art. $3^{\circ}$, inciso IV), e da igualdade (art. $5^{\circ}$, caput), da liberdade (art. $5^{\underline{o}}$, caput) e da proteção da segurança jurídica.

Tal decisão impactou a prática adotiva no Brasil. Até aquele ano, só poderiam pleitear conjuntamente uma filiação adotiva, de acordo com o art. $39, \S 2^{\circ}$, da lei 12010/09, os adotantes casados civilmente ou que mantivessem união estável, "comprovada a estabilidade da família”. Assim posto, pares homossexuais vivenciavam dificuldades de, como parceiros, terem um filho de ambos através da adoção. Vale ressaltar que, mesmo nesse contexto houve, em âmbito jurídico, decisões favoráveis ao pleito $^{10}$.

\section{A análise dos processos. 0 parentesco como valor: os motivos para a adoção homossexual}

Feita a reflexão sobre o impacto da decisão do STF na prática adotiva, passo à análise dos dados documentais ${ }^{11}$. Para discutir as razões que levam à adoção, a partir dos processos, começo narrando a ação de adoção unilateral (perfilhação) proposta, em 2012, por Maria Rita em face do filho adotivo de Jandira, sua companheira amorosa.

Vale ressaltar que, em razão da decisão do Supremo Tribunal Federal, ações de adoções unilaterais começaram a ser ajuizadas por companheiro de declarada orientação homossexual. Até antes dessa data, algumas pessoas que viviam em união consensual decidiam adotar sozinhos. Entretanto, após a decisão do STF, indivíduos que viviam uma situação fática de parentalidade começaram a mover ações para adotar filhos adotivos de seus companheiros. Essa foi a razão que moveu Maria Rita a ajuizar uma ação em uma Vara da Infância e da Juventude na comarca do Rio de Janeiro.

\footnotetext{
${ }^{10}$ Como exemplo há a decisão, pelo Superior Tribunal de Justiça, acerca do recurso especial n. 889852- RS (2006/0209137-4). Trata-se da possibilidade de pessoa que mantém união "homoafetiva" adotar duas crianças (irmãos biológicos) já perfilhadas por sua companheira.

${ }^{11}$ Com o objetivo de preservar o "segredo de justiça", alterei nome, idade, sexo das crianças e dos jovens adotados, assim como dos pretendentes à adoção. Além disso, misturei algumas histórias para evitar que pessoas fossem reconhecidas. Tal recurso não comprometeu, no entanto, a análise do material.
} 
Jandira e Maria Rita, segundo a petição inicial dos "autos", vivem conjuntamente em regime de união estável e "[...] acalentavam o sonho de ter um filho, sendo este mais um objetivo comum de ambas." Como tal desejo foi iniciado antes do ano de 2011, apenas uma delas, Jandira, a companheira da requerente Maria Rita, ajuizou procedimento de habilitação em adoção e passou a visitar várias entidades de acolhimento até encontrar a filha que adotaria. Segundo a mesma petição inicial, não pensaram na possibilidade de adoção conjunta à época porque "temiam que a criança sofresse qualquer tipo de discriminação e preconceito por parte de pessoas que passariam a conviver com um dito novo modelo de família”.

Nesse sentido, pode-se supor que o casal optou por uma espécie de encenação calculada com o intuito de preservar a criança pretendida (DAS, 1999:39). Ao fazer essa escolha, participaram de um tipo de acordo fictício. Supostamente aceitaram silenciosamente a se submeter à ideia de que a constituição das relações de parentesco só pode ocorrer em âmbito heterossexual. No entanto, tal estratégia pode ser lida como uma possibilidade fática de resistência, uma vez que ordinariamente viveriam uma parentalidade e filiação em âmbito da conjugalidade homossexual. De maneira transgressiva, na qualidade de um casal que vive às "margens" do Estado (DAS; POOLE, 2008), seriam elas uma família com filhos. No entanto, na relação com o Estado, tratar-se-ia de uma família composta, por via da adoção, por uma mulher e sua prole.

No entanto, o tempo foi um fator primordial para que o casal deixasse de ser um núcleo "marginal" e passasse a ser uma forma de família reconhecida pelo Estado. Como um agente que trabalha nas relações, o tempo possibilitou que gays e lésbicas, que já se reconheciam como família pudessem buscar por via jurídica, após 2011, sair de uma condição simbolicamente violenta e insegura. Com a interpretação jurídica de que um par homossexual é uma família "homoafetiva", rompeu-se um arranjo fictício. Por essa razão, a ação em questão trata-se de um pedido de reconhecimento de uma situação fática e legitimação de um núcleo de parentesco.

Segundo advogada da requerente, o pedido em questão não se deve à busca de constituição de uma família por meio da filiação. Segundo a mesma, a requerente "desde o momento em que começou a conviver com sua companheira experimentou o verdadeiro sentido de família, com um lar estável, harmonioso, repleto de amor e carinho”. O pleito decorre do

Desejo de ter legalmente a menor também como filha [...]. Assim, a requerente busca pelo presente procedimento formalizar 
uma situação que já existe e que é comum e quer continuar proporcionando à criança amor, carinho, educação, saúde, mas acima de tudo, quer perfilhá-la.

Sendo assim, nas versões produzidas nos processos, essa busca pela adoção, ou mais especificamente pela filiação, pode ser tida como veículo de transformação de uma família homossexual em um núcleo do qual emergem relações de parentesco. Para tanto, há a necessidade de reconhecimento desta por parte do Estado. Sendo assim, compreende-se por que alguns casais homossexuais, que se representam como família, inclusive vivendo uma situação fática de paternidade e filiação, procuram a regularização legal dessa relação.

Além de Jandira e Maria Rita, Bianca e Beatriz buscaram a adoção com o intuito de passarem a ser um núcleo por meio do qual emergem relações de parentesco ${ }^{12}$. Segundo o estudo social ${ }^{13}$ produzido no decorrer do procedimento de habilitação do casal, em 2011, "as requerentes formam um casal homoafetivo e vivem em regime de coabitação há anos [...]”. De acordo com a mesma peça documental, Bianca, "antes de definir a sua homossexualidade, já expressava o desejo da maternidade”. Beatriz, por sua vez, começou a desejar ser mãe aos 19 anos, no mesmo período em que "apresentou uma tendência homossexual". Entretanto, foi Bianca que, em âmbito da conjugalidade em questão, demonstrou o interesse pela adoção, transformando seu desejo em projeto do casal. Com o intuito de amadurecer a ideia, ambas decidiram participar de um programa de "apadrinhamento afetivo"14, originalmente estimuladas pela "vontade de ajudar algumas

\footnotetext{
${ }^{12}$ Segundo Butler (2003:221) "a tarefa seria considerar a sugestão de David Schneider, segundo a qual o parentesco é um tipo de construção, um tipo que não reflete uma estrutura anterior, mas que só pode ser compreendida como prática realizada”.

${ }^{13} \mathrm{O}$ estudo social é um procedimento obrigatório realizado por psicólogos e assistentes sociais, membros da equipe técnica da Vara da Infância da Juventude e do Idoso. Este ocorre tanto durante a habilitação quanto no decorrer do processo de adoção. É um trabalho pericial dirigido aos adotantes, aos genitores e demais envolvidos na ação, por meio de entrevistas, visitas domiciliares e produção de parecer social e psicológico, remetido ao Ministério Público e, posteriormente, ao Juiz da Vara.

${ }^{14}$ Há distintas modalidades de apadrinhamentos possíveis: o afetivo, que se responsabiliza pelo cuidado de uma criança ou adolescente $\mathrm{O}$ material, que trata do auxílio financeiro do(a) afilhado(a). A prestação de serviços, por meio da qual o padrinho/madrinha presta serviços gratuitos ao assistido pelo programa. A participação nesses programas fica sujeita à autorização do Juiz responsável de uma dada VIJI e à avaliação do Setor de Psicologia e Serviço Social.
} 
crianças necessitadas". Assim se aproximaram de alguns infantes acolhidos e "o sonho de adoção começou a ganhar espaço na vida das requerentes". "A partir de então, visitaram alguns abrigos e perceberam que a ideia da adoção já estava delineada e amadurecida [...]".

Nota-se que, nesse caso, a maternidade "socioafetiva" aparece como materialização de um desejo "que sempre existiu", o de ser mãe e, ao mesmo tempo, permanecer homossexual. Essa é a versão que aparece no estudo social realizado no curso do processo de habilitação de Bianca e Beatriz, que, segundo os "autos", "sempre desejaram adotar uma criança" e, por isso, procuraram uma Vara de Infância, da Juventude e do Idoso. Vale ressaltar que a escolha por essa forma de filiação não é unívoca. As motivações são inúmeras e, como pode ser visto, encontram-se relacionadas às vidas dos envolvidos. Além da busca pela maternidade e o desejo de serem "mães adotivas", o fato de terem participado de um serviço de acolhimento, criado para evitar a institucionalização de infantes e jovens, também as conduziu para o projeto parental em questão.

\section{Quando as Ciências Sociais se cruzam com o direito}

Nosprocessos são construídas discussões sobre parentesco e homossexualidade por parte dos integrantes do Poder Judiciário (juízes, membros da equipe técnica - psicólogos e assistentes sociais), por membros da Defensoria Pública, por advogados e por promotores da infância e juventude. Do ponto de vista da viabilidade de um par homossexual ser reconhecido como família e como pais/mães, surgem ordens distintas de discursos. São elas suportadas em saberes psicológicos, sociológicos e antropológicos, cujo propósito é abordar a sexualidade como impedimento ou não à parentalidade. Aborda-se a subjetivação dos sujeitos com ou sem os referentes masculinos e femininos; as mudanças nos modelos de família e as possibilidades de arranjos homossexuais como produtos de relações de parentesco.

Do ponto de vista da concepção euro-americana de parentesco, de acordo com Strathern (2011), há exigência simbólica de que filhos tenham dois pais de sexos distintos, "iguais em termos de doação genética, mas desiguais em termos de papéis" (STRATHERN, 2011:305). Esse modelo, pautado na existência de estruturas universais, é concebido como composto por duas pessoas de sexos distintos com práticas sexuais monogâmicas, cuja finalidade 
é reprodutiva. Nessa ótica universalista ${ }^{15}$, o sistema de parentesco é tido - em termos simbólicos - como organizador das identidades de gênero e sexuais, uma vez que é na dupla referência de um pai e de uma mãe, com a identificação com um deles e o afastamento simbólico do outro, por meio do “complexo de Édipo", que se formarão os sujeitos.

Sendo assim, homossexuais vivendo em parceria e desejando serem pais, se compreendidos deste ponto de vista, podem ser vistos como "contrariando a ordem simbólica”. Essa visão se faz presente nos processos, sobretudo nos pareceres da equipe técnica (psicólogos e assistentes sociais), mas de forma relativamente distinta. Isso porque, em todos os processos envolvendo parceiros homossexuais trabalhados, o posicionamento desses profissionais foi favorável ao pleito, sem isso significar a aceitação plena do parentesco fora do âmbito da heteronormatividade (BUTLER, 2004; 2010; MUSKOLCI, 2009) ${ }^{16}$.

Tal posicionamento pode se ver em algumas peças processuais. A título de exemplo, cito a visão contida no parecer técnico expresso no pedido de habilitação conjunta feita pelo casal Jairo e Joaquim, em 2005, em outro estado brasileiro, e que foi analisada porque fez parte do processo de adoção aberto pelos mesmos em 2011 na comarca do Rio de Janeiro.

O casal vive junto há tempo e amadureceu a ideia de adoção. Eles optaram por tentar conjuntamente obter a habilitação. O perfil de criança desejada era o de uma menina e um menino de aproximadamente cinco ou seis anos de idade. Como esse foi um dos primeiros processos dessa ordem, não só na cidade, mas no País, a sentença demorou em torno de três anos a ser deferida. Após esse período, o juiz responsável decidiu pela possibilidade da adoção conjunta, mas restringiu a idade e o sexo das crianças embasado no "princípio constitucional do melhor interesse da criança e do adolescente". Por meio dessa escolha, o argumento era o de que uma infante ou jovem de

\footnotetext{
${ }^{15}$ Ver Gayle Rubin (1993) e suas reflexões sobre o estruturalismo na antropologia e na psicanálise e seus efeitos nas concepções sobre parentesco, gênero e sexualidade.

${ }^{16}$ Segundo Butler (2010), o mundo ocidental institui a heterossexualidade compulsória e naturalizada a partir da norma de gênero. Essa norma organiza os corpos e suas subjetividades por meio de um binarismo (masculino e feminino) heteronormativo, tornando a homossexualidade um tipo de desvio ininteligível (BUTLER, 2004:116). Inspirado nas reflexões de Butler, Miskolci pontua que [...] "heteronormatividade é um conjunto de prescrições que fundamenta processos sociais de regulação e controle, até mesmo daqueles que não se relacionam com pessoas do sexo oposto. Assim, ela não refere apenas aos sujeitos legítimos e normalizados, mas é uma denominação contemporânea para o dispositivo histórico da sexualidade que evidencia seu objetivo: formar todos para serem heterossexuais ou organizarem suas vidas a partir do modelo supostamente coerente, superior e 'natural' da heterossexualidade". (2009, p.172).
} 
maior idade teria maior discernimento e possibilidade de escolha se desejaria ou não ser adotado por um casal gay. Sendo assim, o adotando deveria ser maior de dez anos e somente do sexo feminino, escolha não fundamentada. Frente a tal sentença, o casal, por entender que a decisão foi discriminatória, recorreu da decisão a uma segunda instância. Dessa apelação, ganharam por unanimidade o direito de adotar conjuntamente sem qualquer restrição. No entanto, houve recurso da apelação por parte do Ministério Público, que recorreu e levou o caso ao Supremo Tribunal Federal (STF) e ao Superior Tribunal de Justiça (STJ). A alegação, além da incompetência da decisão de um juiz da infância e juventude arbitrar sobre questões afeitas ao direito de família, foi a de que casais do mesmo sexo não formam uma entidade familiar e, portanto, não podem adotar conjuntamente. O STF rejeitou o recurso porque não dizia respeito à matéria em julgamento, qual seja a restrição quanto à idade e ao sexo das crianças. No entanto, como tal recurso não tinha efeito restrito, após maio de 2011, quando o STF estendeu o regime jurídico de união estável a casais homossexuais, o casal pôde adotar. $\mathrm{Na}$ peça processual da habilitação, datada de 2005, consta no estudo social o seguinte:

A alegação de que a adoção por homossexuais pode causar distúrbios na identidade sexual do adotado, estudo nesta área tem afastado essa hipótese, embora se reconheça que os filhos herdam muito da história de vida de seus pais. O que se verifica é que a homossexualidade dos pais por si só não determina a identidade de gênero e orientação sexual da criança. No que diz respeito à construção dos papéis de pai e mãe, ocorrerá da mesma forma que nas adoções monoparentais. As funções paternas e maternas necessitamigualmente existir, porém exercidasindependentemente do gênero sexual, pois são funções. A função paterna precisa existir em três vértices: proteção, limite e direção; e a função materna se realizará provendo o vínculo, a nutrição e a organização. Existindo as duas funções, estará garantida à criança sua estrutura psíquica. No caso dos requerentes, percebemos que o equilíbrio de ambos possibilitará, junto com a ajuda das madrinhas e dos amigos que os cercam, suprir de forma saudável essas funções.

Como pode ser visto, esse discurso aciona a visão de que em âmbito do parentesco se dá a estruturação dos sujeitos e que esta depende de referentes masculinos e femininos. No entanto, afirmam que estes não têm de ser 
ocupados necessariamente por homens e mulheres ${ }^{17}$. Há que se atentar para tal posicionamento e sua aparente flexibilidade a um parentesco não heterossexual, uma vez que "de acordo com esse preceito, aqueles que entram nessas relações como não heterossexuais só poderão relacionar-se se assumirem o papel de Mãe e de Pai”. (BUTLER, 2003, p.251).

Ressalta-se que a sexualidade do "requerente" é posta em questão pela equipe técnica, o que não ocorre em outros procedimentos que envolvem heterossexuais. A homossexualidade é levada em conta quando se trata de definir a "aptidão" de uma pessoa para ser pai ou mãe adotivo. Isso porque, de acordo com Butler (2003, p. 221), no mundo ocidental, a heterossexualidade foi tornada legítima, freando em termos práticos e simbólicos outras possibilidades concebidas como desviantes ou anormais.

De acordo com Foucault (1993), a partir dos séculos XVI, inventou-se no Ocidente uma scientia sexualis. Multiplicaram-se, assim, discursos sobre o sexo que, como dispositivos, acabaram por normalizá-lo. Entretanto, o século XIX é um momento de destaque por ter um crescimento de produções de saberes médicos, que, sob uma suposta neutralidade científica, produzem verdades sobre o sexo. Houve, assim, a legitimação de preferências e práticas sexuais e, com destaque no século XIX, cresceu a produção de uma verdade científica sobre o sexo, multiplicando-se as categorizações de "má" conduta sexual. Desta forma, a prática sexual entre dois parceiros de sexos distintos, em âmbito do casamento, foi transformada ideologicamente em um valor universal, expulsando-se, assim, para a esfera da anormalidade, do desvio e da perversão as atividades sexuais divergentes desse modelo. Visão semelhante consta na sentença de habilitação de João e Rogério que, em 2011, ajuizaram ação de adoção de meninas que conheceram em "programas de apadrinhamento afetivo", do qual faziam parte.

O psicólogo Roberto Granã ensina que "todos os desvios sexuais são, em qualquer idade, essencialmente, desvios sexuais infantis[...] o homossexualismo é fruto de um pré-determinismo psíquico

\footnotetext{
${ }^{17}$ Zambrano (2006), ao refletir sobre "a emergência de famílias constituídas por pais/mães homossexuais, travestis e transexuais”, aborda o impacto que os princípios teóricos da psicanálise tiveram sobre os discursos e práticas de diferentes profissionais, como juristas psicólogos e assistentes sociais responsáveis em tratar do assunto. Segundo a autora, essa influência se fez presente na França. É possível afirmar que tais saberes foram incorporados também nos discursos e nas práticas dos profissionais do campo do direito do Brasil, responsáveis em tratar do assunto.
} 
primitivo. Origina-se nas relações parentais das crianças, desde a sua concepção até os 3 ou 4 anos de idade, será mais ou menos corroborada de acordo com o ambiente em que ela se desenvolva, o que posteriormente determinará sua orientação sexual definitiva"[...]. Evidentemente que o Poder Judiciário não seria lícito expor criança já fragilizada a um contexto de opera bufa, mas no caso presente os requerentes demonstraram publicamente uma atitude de vida adequada, com uma união de vidas, em que construíram o relacionamento sob forte resistncia exterior [...]. (grifo meu)

Nota-se que, em concomitância com um discurso essencialista e patologizante sobre condutas, emergem positivações morais dos envolvidos. Demonstra-se que, "apesar de gays", vivem relações duradouras pautadas no "afeto, no companheirismo e não exclusivamente no sexo”. Ideia que pode ser vista claramente em um parecer técnico feito no curso de habilitação do já citado casal Jairo e Joaquim, em 2011.

Parecer técnico: MM Juiz, trata-se de um casal homoafetivo, que vivem sob regime contratual de união estável e possuem como principal desejo em suas vidas se tornarem pais [....]Relataram que no relacionamento não existe homem ou mulher, agem desfrutando das habilidades de cada um e assim se complementam [.... $\mathbf{A}$ união é pautada na compreensão, na confiança, no amor, fidelidade, estão juntos porque um tem carinho pelo outro e a relação não é baseada apenas no sexo[....] (grifo meu).

Aproxima-se assim, nos termos de Rubin (2003), um "mal" de um "bom" sexo. De acordo com a antropóloga, o mundo ocidental traçou limites - que funcionam como um sistema ideológico da mesma forma que o racismo, o etnocentrismo e o chauvinismo religioso - do que considera, em termos de expressão e práticas sexuais, um "bom" e um "mau” sexo. Ao hierarquizar condutas sexuais, $\mathrm{O}$ ocidente tornou algumas aceitas, outras toleradas e outras desprezíveis. Nessa lógica, atos sexuais passaram a ser avaliados de acordo com um sistema piramidal de valores sexuais. Segundo a autora, heterossexuais maritais e reprodutivos estariam sozinhos no topo da pirâmide erótica, seguidos de heterossexuais monogâmicos não casados e que não reproduzem. Casais lésbicos e gays estariam no meio dessa pirâmide. Por fim, estariam "sapatões", os gays promíscuos e, na base, os mais desprezados, como os transexuais, travestis, fetichistas, sadomasoquistas, prostitutas etc. (RUBIN, 2003, p. 50). 
Retornando à positivação de gays e lésbicas, nesse tipo de processo pode ser destacada a manifestação do setor técnico da VIJI no processo de Bianca e Beatriz. Elas vivem juntas há anos e nutriram o desejo de serem mães e, por isso, habilitaram-se. Iniciaram visitas às casas de acolhimento infanto-juvenil, além de participarem de "programa de apadrinhamento afetivo", por meio do qual conheceram a filha. Segundo o estudo social feito pelo setor técnico, "a família homossexual é capaz de preencher as necessidades biopsicossociais da criança”. Além disso, é manifesta por outros técnicos no processo de João e Rogério a necessidade de se considerar que atualmente a sociedade convive com diferentes formas de família e se mostra mais aberta para aceitar as novas configurações, tais como as "monoparentais", as constituídas por procriações medicamente assistidas e as "homoafetiva". Nessa ordem de produção, gays e lésbicas são postos como moralmente aceitáveis e, para tanto, psicólogos e assistentes sociais valem-se de produções antropológicas e sociológicas atuais para fundamentar seus argumentos, como pode ser visto:

Para fundamentar nosso parecer, citamos André Diniz e Cláudia Borges: a bibliografia que discorre especificamente acerca da paternidade homossexual busca compreender as tendências que tais estudos desenvolvem no processo de análise desse fenômeno e as possíveis diferenças que existem entre as criações de filhos por homossexuais e heterossexuais. Stacey e Biblarz (2003) fazem um levantamento dos argumentos que vão contra e a favor da paternidade/maternidade homossexual. Estes autores afirmam que os posicionamentos desfavoráveis alicerçam-se na concepção burguesa da família e na hipótese da homossexualidade configurarse em patologia ou anomalia. Em contrapartida, os discursos favoráveis buscam tecer uma crítica histórica à patologização da homosssexualidade, compreendendo a família e a sexualidade como instituições e dimensões construídas sócio-historicamente DINIZ; BORGES. In: GROSSI; UZIEL; MELLO (2007, p.260).

Sendo assim, discursos das ciências humanas e sociais surgem como dispositivos de "verdades", atestando o sucesso de uma adoção feita por homossexuais. É nesse sentido que, no estudo social de Bianca e Beatriz, afirma-se que "a homossexualidade dos pais por si só não determina a identidade e orientação sexual da criança”. O mesmo argumento é encontrado em sentença cujo juiz cita não só psicólogos, mas também pediatras como selo de garantia de que pais homossexuais não criarão seres "pervertidos ou desviantes". 
Contudo, estudos científicos de respeitadas instituições (a Academia Americana de Pediatria e as universidades de Virginia e Valencia) apontam não haver qualquer inconveniente na adoção por companheiros em união homoafetiva, pois o que realmente importa é a qualidade do vínculo e do afeto presente no meio familiar que ligam as crianças aos seus cuidadores.

\section{Da homossexualidade à "homoafetividade"}

No material investigado, a adoção homossexual é tratada por profissionais do campo do Direito, a partir de princípios constitucionais e direitos fundamentais contemplados na Constituição Federal Brasileira de 1988. São considerados decisivos para o enquadramento da questão o princípio da igualdade; o da liberdade; o da dignidade da pessoa humana; o princípio da segurança jurídica e do melhor interesse da criança e do adolescente. Trata-se ainda da família e a possibilidade de esta ser composta por pares homossexuais. São abordadas as transformações sociais por que essa instituição passou e sua consequente mudança no ordenamento jurídico: a passagem de um modelo "matrimonializado" e "patrimonializado" e sua "repersonalização" em face dos princípios constitucionais da dignidade da pessoa humana, da igualdade, da solidariedade e do afeto.

Para que esse pleito pudesse ser abordado positivamente nos processos, algumas transformações ocorreram no cenário jurídico brasileiro no que tange aos direitos das minorias sexuais. Diversas demandas, como partilha de bens, direito sucessório, previdenciário, mudança de sexo, de nome e de identidade de gênero, direito ao casamento, a ser reconhecido como família, à reprodução assistida e à adoção, vêm impactando o Judiciário nacional. Este vem se manifestando em decisões proferidas pelo Superior Tribunal de Justiça (STJ) e pelo Supremo Tribunal Federal (STF), favoravelmente à maioria das questões propostas. Em razão disso, esses órgãos são acusados de atuar fora de sua esfera de competência, agindo como se legislassem. Vale ressaltar que a decisão de tribunais superiores não tem efeito de lei. Algumas são "vinculantes" - como as do Superior Tribunal de Justiça (STJ) e do Superior Tribunal Federal -, promovendo a obediência obrigatória em território nacional. Outras, como as dos Tribunais Estaduais e dos Superiores, são apenas referências capazes de orientar diferentes julgados.

Um grande destaque tem sido dado à já abordada decisão proferida pelo Supremo Tribunal Federal no julgamento da Ação de Descumprimento de 
Preceito Fundamental ADPF 132 e da Ação Direta de Inconstitucionalidade ADI 4277 que, em maio de 2011, reconheceu a união de homossexuais como entidade familiar e merecedora de proteção do regime jurídico de união estável. Tal decisão impactou a prática adotiva no Brasil. Isso pode ser visto na ação de adoção unilateral aberta por Maria Rita em face do filho adotivo de sua companheira. Segundo inicial,

Trata-se aqui de um caso de adoção unilateral, onde a requerente pleiteia a perfilhação do filho de sua companheira [...]O Código Civil em seus artigos 1.723 a 1.726, com a interpretação fixada pelo Supremo Tribunal Federal os autos da Ação Direta de Inconstitucionalidade (ADI) $\mathrm{n}^{\mathrm{o}} 4277$ e da Arguição de Descumprimento de Preceito Fundamental (ADPF) nº 134, e demais princípios constitucionais aplicáveis, em especial os da igualdade, a vontade, e o da dignidade da pessoa humana, constituem-se, igualmente, em base jurídica para o presente pedido.

Em ações abertas antes de 2011, é comum encontrar argumentos sobre a ausência de previsão legal sobre a possibilidade de reconhecimento de famílias homossexuais e a respeito da adoção conjunta por gays e lésbicas. Essa ausência é tratada ora como impedimento ao pleito, ora como algo que deve ser ultrapassado à luz de analogias entre leis existentes e interpretações conforme princípios constitucionais. Segundo sentença proferida em 2005, em face do requerimento de habilitação conjunta do casal Jairo e Joaquim, é dito:

Nós operadores do Direito, temos que nos preparar para, enquanto a Lei não for editada, assegurar os direitos contidos constitucionalmente e estendidos a essa minoria, conscientes de que a Lei existente não pode servir de limites de prestação jurisdicional [...] Para tanto, é necessário que façamos uma reflexão por meio de princípios e direitos fundamentais que são decisivos para o enquadramento ético e jurídico da questão [....]. Não há como se excluir legitimamente pessoas do mesmo sexo da categoria entidade familiar e nem regime jurídico da união estável, se o que as une é a mesma afetividade e o mesmo projeto de vida comum que ligam as pessoas de sexo oposto. Vale dizer ainda que a Constituição de 1988 faça menção apenas à união estável entre homem e mulher, no que foi seguida pela legislação ordinária, deixou o tema aberto à evolução dos costumes e do direito [...] 
Jáopromotor dejustiça,nojácitadorecurso daapelação propostopelocasal, manifesta-se sobre a impossibilidade da adoção por homossexuais. Defende que em, nosso ordenamento jurídico constitucional e infraconstitucional, só se reconhece como família a união entre pessoas do mesmo sexo e que só existe previsão legal para a adoção de homens e mulheres casados ou vivendo em regime de união estável. Segundo o mesmo, nos termos do art. 1622 do Código Civil de 2002, "ninguém pode ser adotado por duas pessoas, salvo se forem marido e mulher, ou viverem em união estável" e de acordo com Art. 1.723 só é "reconhecida como entidade familiar a união estável entre o homem e a mulher, configurada na convivência pública, continua e duradora e estabelecida com o objetivo de constituição de família”.

Em algumas peças analisadas, os oficiantes do Direito elaboram considerações sobre a constitucionalização da família e sobre a importância do "princípio do melhor interesse da criança e do adolescente". Buscam, assim, positivar ou tornar negativa a prática adotiva gay e lésbica. A título de exemplo, a advogada do casal João e Rogério afirma que:

[...] Desde a promulgação da Constituição de 1988, no que diz respeito à família deslocou-se do casamento para as relações familiares[...]. Desta forma, o conceito tradicional de família se modificou, não se restringindo mais ao casamento, nem tampouco às pessoas do sexo oposto. [...] união pelo amor e pelo afeto que caracterizam a entidade familiar e não mais o casamento ou diversidade de gêneros. É, antes disso, afeto a mais pura exteriorização do ser do viver, de forma que a marginalização das relações mantidas entre pessoas do mesmo sexo constitui forma de privação do direito à vida, bem como viola os princípios da dignidade da pessoa humana e da igualdade.

De acordo com Torres (2009, p.75), com o advento da Constituição de 1988, "a família tornou-se um espaço de realização existencial das pessoas em suas dignidades e como lugar por excelência de afetividade, cujo fundamento jurídico é o princípio da solidariedade, consagrado em seu artigo $3^{\circ}$, inciso I". Ocorreu, segundo o mesmo, uma mudança de concepção doutrinária promovendo uma "personalização" da organização familiar. Passou essa instituição a ser interpretada à luz do princípio fundamental da dignidade da pessoa humana. Tal mudança esvaziou conceitos "patrimonializados" e "matrimonializados" de família presentes no Código Civil de 1916, substituído por outro, em 2002. 
Através dessa mudança paradigmática, propalada pela Constituição Federal de 1988 e materializada no Código Civil de 2002, concebeu-se a família como plural e pautada na "afetividade". Passou a ser considerada "eudemonista", com a função de garantir a felicidade de seus membros. Baseado nessas mudanças paradigmáticas, as relações "homoafetiva"estruturadas no "afeto", na "solidariedade", na "assistência mútua" e no "respeito" - puderam ser compreendidas como entidade familiar conjugal.

Nota-se que, nos processos trabalhados, essas doutrinas citadas são transformadas em fundamentos favoráveis à adoção por casais homossexuais, como já na citada sentença favorável à habilitação conjunta do casal Jairo e Joaquim,

[...] a) a uniões homoafetivas são fatos lícitos e relativos à vida privada de cada um, sendo papel do Estado e do Direito, em relação a elas como a tudo mais, o de respeito à diversidade e contribuir para a superação do preconceito e da discriminação; b) a Constituição de 1988 não contém regra expressa acerca de orientação sexual ou relações homoafetivas; c) a regra do art. 226 parágrafo $3^{\circ}$ da Constituição, que se refere ao reconhecimento da união estável entre homem e mulher, representou a superação da distinção que se fazia anteriormente entre o casamento e as relações de companheirismo e trata-se de norma inclusiva, de inspiração antidiscriminatória; d) os princípios constitucionais da igualdade, da dignidade da pessoa humana e da liberdade impõem a extensão do regime jurídico da união estável ás uniões homoafetivas; e) ainda, admitida a lacuna normativa, seria de se aplicar a analogia e sendo a situação mais próxima à da união estável pessoas do mesmo sexo, a união estável entre homem e mulher por terem ambas como características essenciais a afetividade e o projeto de vida comum $[\ldots]$.

Além do "afeto", que transforma um casal homossexual em uma família "homoafetiva", advogados, promotores, defensores e juízes se valem do princípio da integral proteção da criança e do adolescente para tratar do tema. Segundo Vechiatti (2012, p.499), o ordenamento jurídico brasileiro concede, por meio de sua Carta Constitucional e do Estatuto de Criança e do Adolescente (ECA), esse princípio para salvaguardar infantes e jovens de todo e qualquer mal.

Nos documentos analisados, esse princípio surge de formas distintas. De um lado, argumenta-se que a adoção pleiteada por casais homossexuais 
atende ao "superior interesse da criança e do adolescente" por abrir maiores possibilidades para que exerçam o direito à convivência familiar e comunitária.

Nessa perspectiva, quanto mais pessoas queiram adotar, mais infantes e jovens poderão gozar do direito de estar em família. Tal argumento está presente na petição inicial da ação proposta pelo casal de gays Brandão e Aristides, que vivem juntos há cinco anos. Um deles já vivera união heterossexual e teve filhos. O outro nunca teve filhos, além dos que eles adotaram. Em razão da união atual, decidiram pelo projeto de filiação adotiva. Segundo a petição inicial:

Vale finalizar dizendo que o objetivo de toda a nossa busca é atender o superior interesse da criança ou adolescente que se pretende inserir na família substituta, seja ela de que modelo for (monoparental, inter-racial, reconstruída, homoafetiva), sendo que neste particular é pertinente que se tenha claro que tudo o que uma criança ou adolescente institucionalizado quer e precisa é de uma família, logo devemos pensar na proteção de cada uma delas, que têm o direito de crescer dentro de família [...].

Por outro lado, esse princípio pode ser usado também para limitar ou restringir a possibilidade da adoção por homossexuais. À luz da representação de que pais adotivos gays e lésbicas podem expor seus filhos às discriminações em razão de sua orientação sexual, foi, por exemplo, defendido o argumento que se segue em uma sentença de habitação de Jairo e Joaquim já antes citada:

[...] DA OPINIÃO DA CRIANÇA QUANTO A SER ADOTADA OU NÃO POR CASAIS HOMOAFETIVOS: "em vista da proteção integral e do melhor interesse da criança/adolescente acima discorrido, coloca-se como necessário a opinião da criança de ser adotada ou não por pessoas de uma união homoafetiva,sendo levado ao seu conhecimento de forma simples e precisa todas as dificuldades e preconceitos enfrentados por ter 'pais ou mães' homoafetivos para que se sinta interagindo com o próprio futuro[...] é imprescindível que o adotado se sinta confortável, amado e feliz dentro do seio familiar adotante e para que essa escolha seja possível, pois se viu nitidamente que necessário o é dependerá que a criança/adolescente disponha de idade com capacidade de discernimento para expressar perante o Juízo suas insatisfações, desejos, necessidades, emoções e opiniões a respeito da possibilidade de um casal homoafetivo adotá-la. [...]. 
Em diferentes pesquisas que tratam da visão dos operadores do Direito sobre parentalidades adotivas, Uziel (2007) e Zambrano (2006) relatam terem encontrado, por parte desses profissionais, uma maior preocupação com "superior melhor interesse da criança e do adolescente" quando os adotantes são homossexuais e/ou travestis e/ou transexuais do que quando os requerentes são heterossexuais.

Pude perceber, de forma semelhante às considerações das autoras que, quando os pretendentes são gays e lésbicas, esses são abordados como se fossem virtuais ameaças aos pretensos filhos. Entretanto, como ressalta Morelo (2014), esses mesmos requerentes podem ser interpretados como estivessem se afastando dos conteúdos "poluidores" associados tradicionalmente à orientação homossexual. Isso porque materializam também a incorporação de valores "tradicionais de família" por meio da aspiração à parentalidade. Assim, por meio dessa chave interpretativa, deixam de ser analisados exclusivamente como se fossem uma "ameaça" e passam a ser vistos também como uma "alternativa" para que infantes e jovens aptos à adoção tenham suas famílias.

\section{Considerações finais}

A questão central que norteou este artigo foi investigar, por meio da análise em processos de adoção, como na comarca do Rio de Janeiro são construídos os motivos que levam homossexuais à adoção e como aparecem, nestes documentos, as visões sobre o assunto produzidas por integrantes do Poder Judiciário (juízes, membros da equipe técnica - psicólogos e assistentes sociais), membros da Defensoria Pública, Promotores que militam na área da infância e da juventude.

Nas versões documentais, o que move casais gays e lésbicos ao projeto adotivo é o desejo de transformarem suas famílias em um núcleo do qual emergem relações de parentesco. Além disso, buscam as Varas da Infância e da Juventude para regularização de uma situação fática de paternidade e filiação vivida por ambos, mas só reconhecida pelo Poder Judiciário a um deles até o momento da ação. Afora o reconhecimento de uma situação fática, tanto para gays quanto para lésbicas, segundo o universo pesquisado, a adoção aparece como materialização de um desejo "que sempre existiu", o de ser mãe e de ser pai e, ao mesmo tempo, permanecer homossexual.

No que tange às visões sobre o assunto produzidas pelos profissionais da área da infância e da juventude, o caminho trilhado foi o de investigar como 
se conectavam, em suas argumentações, as discussões sobre parentesco e homossexualidade. Além disso, busquei compreender como se articulavam as produções jurídicas e os saberes oriundos das ciências humanas e sociais, cuja tendência era a de despatologizar as "sexualidades divergentes".

Por meio desse percurso, observei que para alguns desses profissionais um par homossexual precisa ser reconhecido como família para ter o direito de estabelecer relações de parentesco/filiação. É necessário que ambos sejam vistos como sujeitos "estáveis", que pautam suas relações no "afeto" e não no sexo. Assim podem cuidar de crianças na qualidade de pais e mães. Apesar de visões dissonantes, sobretudo por parte da promotora da infância e da juventude, essa perspectiva foi predominante. Em sua grande maioria, juízes, defensores públicos e advogados consideraram gays e lésbicas aptos a serem pais e mães conjuntamente porque vivem uma vida calcada na "assistência mútua", na "solidariedade", no "afeto" e no "respeito".

Notei também que, dentre as ações pesquisadas, os saberes psicológicos, sociológicos e antropológicos são usados por defensores, psicólogos e assistentes sociais com a intenção de retirar a homossexualidade do lugar de patologia, possibilitando, assim, a parentalidade gay e lésbica. Nessa lógica, homossexuais podem ser pais e mães em âmbito conjugal. No entanto, ao filiarem crianças e adolescentes, deverão exercer funções parentais condizentes com o parentesco heterossexual. Precisam desempenhar funções paternas (proteção, limite e direção) e maternas (vínculo, nutrição e organização), e estas devem ser divididas entre os parceiros.

\section{Referências}

ABREU, Domingos.

(2002). No bico da cegonha: Histórias de adoção e da adoção internacional no Brasil. Rio de Janeiro: Relume Dumará.

BOURDIIEU, Pierre.

(1989). A força do direito. Elementos para uma sociologia do campo jurídico. In: Pierre Bourdieu; 0 poder simbólico. Lisboa: DIFEL. p. 209-255.

BITTENCOURT, Sávio. (2010). A nova Lei de Adoção. Do abandono à Garantia do Direito à Convivência Familiar e
Comunitária. Rio de Janeiro: Lumen Juris Editora.

BUTLER, Judith.

(2010). Problemas de gênero: feminismo e subversão da identidade. Rio de Janeiro: Civilização Brasileira.

(2004). Gender regulation. In: Judith Butler; Undoing gender. New York and London: Routledge. p.40-57.

(1989). 0 parentesco é sempre tido como heterossexual?. Cadernos Pagu, n. 21, p. 219260. 
CHAVES, Mariana.

(2012). Homoafetividade e direito: proteção constitucional, uniões, casamento e parentalidade. Curitiba: Juruá.

DAS, Veena.

(2007). Life and words: violence and the descent into the ordinary. Berkeley: University of Califórnia Press.

DAS, Veena; P0OLE, Deborah.

(2008). El estado y sus márgenes. Etnografías comparadas. Cuadernos de Antropología Social, n. 27, p. 19-52.

DIAS, Berernice.

(2011). União homoafetiva: preconceito e a justiça. São Paulo: Ed. Revista dos Tribunais.

FOUCAULT, Michel.

(1993). História da sexualidade I: a vontade desaber. Rio de Janeiro: Graal.

LUNA, Naara.

(S.d.). Natureza humana criada em laboratório: biologização e genetização do parentesco nas novas tecnologias reprodutivas. História, Ciências e Saúde, v. 12, n², p. 395-417.

MUSKOLCI, Richard.

(S.d.). A teoria queer e a sociologia: o desafio de uma analítica da normalização. Sociologias, ano $11, n^{\circ} 21$, p. 150-182.

MORELO, Rafael.

(2014). Atrás do processo tem gente: Homoparentalidade e suas repercussões no universo da adoção. Dissertação de mestrado apresentada ao Programa de Pós-graduação em Ciências Sociais da Universidade Federal Rural do Rio de Janeiro.

PRITCHARD, E.E. Evans.

(1978). Feitiçaria, oráculos e magia entre os Azande. Rio de Janeiro: Zahar.

RUBIN, Gayle.

(S.d.). 0 tráfico de mulheres: notas sobre a economia politica do sexo. SOS Corpo, n;1, p.1-31.
RUBIN, Gayle.

(2003). Pensando sobre Sexo: Notas para uma teoria radical da política da sexualidade. Cadernos Pagu, no. 21. p. 01-88

STRATHERN, Marilyn.

(1995). Necessidade de Pais, Necessidade de Mães. Revista Estudos Feministas, V.3, N.2, p. $303-329$.

TORRES, Aimbere Francisco.

(2009). Adoção nas relações homoparentais. São Paulo: Atlas.

UZIEL, Ana Paula.

(2007). Homossexualidade e adoção. Rio de Janeiro: Garamond.

VECCIHATII, Paulo Roberto.

(2012). Manual da homoafetividade: da possibilidade jurídica do casamento civil, da união estável e da adoção por casais homoafetivos. Rio de Janeiro: Forense / São Paulo: Método.

VIANNA, Adriana de Resende Barreto.

(2002). Limites da menoridade: tutela, família e autoridade em julgamento. Tese de doutorado apresentada ao Programa de Pós-Graduação em Antropologia Social / Museu Nacional da Universidade Federal do Rio de Janeiro.

ZAMBRAN0, Elizabeth.

(2006). Parenatlidade 'impensáveis': pais/ mães homossexuais, travestis e transexuais. Horizontes Antropológicos, ano 12, n. 26, p. 123-147.

\section{Acórdãos, resoluções, códigos e legislações}

BRASIL. LEI No 12.010, DE 29 DE JULHO DE 2009. Disponivel em http://www.jusbrasil.com.br/ legislacao/818490/lei-12010-09 . Acesso em 5 de out. 2010

ESTATUTO DA CRIANÇA E DO ADOLESCNTE E A LEGISLAÇÃO CORRELATA. Lei no 8069/90, de 13/07/90 Atualizada e legislação correlata. Associação Brasileira dos Magistrados da Infância e da Juventudade. Rio de Janeiro, 2004.207 p. 
RESOLUÇÃO. Disponível em http://www. cremero.org.br/index.php/2011/01/06/ conselho-federal-de-medicina-estabelecenovas-normas-para-reproducao-assistida. Acesso em:21 fev. 2010.

TRIBUNAL DE JUSTIÇA DO ESTADO DO PARANÁ. TJPR, AC 529.976-1, Rel. Juiz Conv. De'ArtagnanCerpa Sá, j. 11/03/2009. Disponível emhttp://www. direitohomoafetivo.com.br/jurisprudencia. php?a=2\&s=5. Acesso em: 20 jan. 2013.
SUPREMO TRIBUNAL FEDERAL.Ação direta de inconstitucionalidade (Med. Liminar) 4277. http://www.stf.jus.br/portal/principal/ principal.asp. Acesso em: 10 jan. 2013.

\section{Recebido em}

maio de 2014

Aprovado em

novembro de 2014 